\title{
Diversity and Abundance of Corn Warehouse Pest Insect in Sumbawa District, West Nusa Tenggara
}

\section{Muhammad Zulkarnain, Muhammad Sarjan*, Tarmizi}

Masters in Dry Land Resources, Mataram University, Indonesia

* Coressponding Author: Muhammad Sarjan

Email: $\underline{\text { m_sarjan@unram.ac.id }}$

\begin{abstract}
Warehouse pest insects can reduce the quality and quantity of corn stored in warehouses. This study aims to examine the diversity and abundance of warehouse pest insects that infest corn in the Sumbawa Regency warehouse. The study was conducted from May to September, located in Sumbawa Regency, covering the East, Central and West regions. The identification of pest insects was carried out at the Biotechnology Laboratory, Faculty of Agriculture and Biology Laboratory, Faculty of Mathematics and Natural Sciences, University of Mataram. The data is processed and reviewed using descriptive methods. The results showed that warehouse pest insects that infest corn in storage warehouses mostly came from the OrdoColoeptera and Hemiptera.
\end{abstract}

Keywords- Pest Insect, Corn Storehouse, Sumbawa Regency.

\section{INTRODUCTION}

Sumbawa Regency is one of the biggest corn producers in West Nusa Tenggara. Recorded in the data of the Agriculture Office of Sumbawa Regency (2018), Sumbawa Regency is able to produce corn nearly $60 \%$ higher than from 2012 to 2016, or with an average production achievement of 299,048 tons in that year.

High corn production in Sumbawa Regency requires storage warehouses during the post-harvest period. Warehouse as a storage place for corn commodity is one of the post-harvest supporting technologies before food arrives in the hands of consumers. The risk that must be faced while corn is in storage during storage is a decrease in quality and quality caused by insect pests. The decline in the quality and quality of corn can cause no small losses (Halid and Yudawinata, 1983). According to Morallo\&Rejesus (1978) in Wahyuningsih (2000), damage to food stored in warehouses can result in losses of up to $5 \%$ to $10 \%$. This statement was reinforced by Christensen and Kauffmann (1969) who suggested that of the estimated total loss of grain worldwide at least 50 percent was caused by insects.

Corn damage in storage is generally caused by infestation by pests. According to Rees (2004), there are a number of pest insects that infest storage material in a storage warehouse. The warehouse pest insects that infest generally come from the insects of the OrdoColeoptera and Lepidoptera, and the rest come from the OrdoOrthoptera and Psocoptera.
Quality assurance and quality of maize during storage at the warehouse needs to be done in Sumbawa Regency. One of the first steps to maintaining quality assurance is to obtain data on diversity and abundance of warehouse pest species through identification of pests in the storage warehouse. But to date, information and reports on pest insect species in storage warehouses in Sumbawa Regency have not been reported by all parties, either from academic researchers or the local Agriculture Service. Therefore, this research needs to be carried out to examine the diversity and abundance of warehouse pest insects that infest corn in the Sumbawa Regency corn storage warehouse.

\section{MATERIALS AND METHOD}

The study was conducted from May to September 2019 and was carried out in two stages, namely the field and the Laboratory. Field research was carried out for warehouse pest insect sampling which took place in three different regions. The three regions cover the East, Central and West Regions. There are two storage warehouses in each region, so we get six locations of the corn storage warehouse. The West Region consists of Rhee District with one warehouse (UD. Ai Salan) and one warehouse in Utan District (Abd. Gani's Warehouse), the Middle Region includes two warehouses in UnterIwes District (PT. Segar Agro Nusantara and CV. RestuSejati), and two corn warehouses in the Eastern Region including Plampang District (CV. FajarTerang and UD. Amanah). Data collection was carried out 4 times at 7-day 
intervals to obtain data on diversity and abundance of corn barn pest insects. Data collection at the study site was carried out in 3 ways, namely sampling of corn infested with pest insects on the staple and warehouse floor, as well as making insect trap traps (Light Trap, Yellow Sticky Trap, Bait Trap and Pitfall Trap).

Laboratory research is carried out to identify insect pest sheds. The identification process was carried out at the Biotechnology Laboratory, Faculty of Agriculture and Biology Laboratory, Faculty of Mathematics and Natural Sciences, University of Mataram. Corn barn pest insect identification is carried out based on morphological samples, namely based on color, body shape, antennae, size and shape of wings, and the number of tarsals with the help of Borror identification books. The diversity and abundance of pest insect populations are calculated using the Shanon-Weiner formula with the equation $\mathrm{H}{ }^{\prime}=-\sum \mathrm{Pi} \ln \mathrm{Pi}$ for insect diversity, and $\mathrm{Pi}=\mathrm{ni} / \mathrm{N} \times 100 \%$ for insect abundance. The data obtained is then processed, reviewed and discussed descriptively.

\section{RESULTS AND DISCUSSION}

\section{Diversity of Insect Pests in Corn Warehouses in Sumbawa Regency}

The Ordo insects that were identified into the insect pests of corn warehouses in the three warehouse storage areas was found as many as 3 Ordo, including the OrdoColeoptera, Lepidoptera, and Psocoptera which were found in all storage warehouse areas. The OrdoColeoptera, which consists of 8 families, 11 genera and 12 species. Then followed by the Ordo Lepidoptera with 5 families, one genus and one species, and the OrdoPsocoptera with family, genus and species numbering one.

The same results were found in families, genera, and species for the Central and Eastern Regions, except the Western Region which showed different identification results from the two storage regions mentioned earlier. From a total of 12 families, 15 genera, and 16 species of insect maize pest identified in the Central and Eastern Region, not found 4 families from 12 families in the Western Region, namely Ptinidae, Silvanidae, Pyralidae, Psyllipsocidae, and one species (D. minutus) of the family Bostrichidae. In addition to these 4 families and one species, the same families, genera, and species found in the Central and Eastern regions (Table 2).

The West Region has fewer identified pests of corn warehouses compared to the other two regions (Table 2). The result was thought to be caused by the smallest size and size of the warehouse compared to the other two regions and the physical condition of the corn storage warehouse was quite good. The reverse results apply for the East and Central Region which has a warehouse with a larger size and relatively good physical condition.

The OrdoColeoptera is the most commonly found Ordo in all three warehouse areas (Table 2). This is because the insects of the Ordo are grain-eating insects. These results are consistent with the results of the research of Haines (1991) which mentions the ordoColeoptera is a postharvest insect pest that most damages grain storage materials such as corn compared to the Ordo Lepidoptera and Psicoptera. Sembel et al. (2002) corroborate previous reports that 10 species of pests were identified as graineating pests including Sithophilussp, Triboliumsp, Carpophilussp, Rhyzopertasp, Oryzaepilussp, Ahasverussp, and Criptoplestessp originating from the OrdoColeoptera. The OrdoColeoptera which attacks grain storage material is caused by the ability of insects from the ordo to adapt quickly to their environment. This is in accordance with the opinion of Wagiman (2015) which states that the OrdoColeoptera is a type of pest insect that is fast breeding and can adapt to the environment that is less supportive for its life cycle.

In total, there are 3 Ordo found in all three warehouse areas and 16 species are almost found in all three warehouse areas. The results show that species diversity is almost evenly distributed across the three regions. Based on the diversity index data shown in Table 1 explains that, the three regions have low species diversity because they have a diversity index value of less than $1\left(\mathrm{H}^{\prime}<1\right)$. This condition reinforces that the diversity of insect pests in corn warehouses is almost equal in the three regions of the Sumbawa Regency warehouse. This happens because the environment is homogeneous in the three warehouse storage areas. Krebs (1978) explains that the more heterogeneous a physical environment the more complex the flora and fauna community in a place is scattered and the higher the diversity of its species.

Table 1. Corn Insect Diversity Index in Corn Storage Warehouses, Sumbawa Regency

\begin{tabular}{cc}
\hline Region & Diversity Index $\left(\mathbf{H}^{\prime}\right)$ \\
\hline West & 0.84 \\
Middle & 0.20 \\
East & 0.83 \\
\hline
\end{tabular}


Tabel 2. Keragaman Serangga HamaGudang Jagung di Gudang PenyimpananKabupaten Sumbawa

\begin{tabular}{|c|c|c|c|c|c|c|}
\hline \multirow[t]{2}{*}{ Ordo } & \multirow[t]{2}{*}{ Family } & \multirow[t]{2}{*}{ Genus } & \multirow[t]{2}{*}{ Spesies } & \multicolumn{3}{|c|}{$\begin{array}{l}\text { Found in Regional Storage } \\
\text { Warehouse }\end{array}$} \\
\hline & & & & West & Midle & East \\
\hline \multirow[t]{11}{*}{ Coleoptera } & \multirow[t]{2}{*}{ Bostrichidae } & Rhyzopertha & R. dominica & + & + & + \\
\hline & & Dinoderus & D. minutus & - & + & + \\
\hline & \multirow[t]{2}{*}{ Curculionidae } & Anthribidae & A. fasciculatus & + & + & + \\
\hline & & Sitophilus & S. zeamais & + & + & + \\
\hline & Dermestidae & Attagenus & A. fasciatus & + & + & + \\
\hline & \multirow[t]{2}{*}{ Nitidulidae } & \multirow[t]{2}{*}{ Carpophilus } & C. lugubris & + & + & + \\
\hline & & & C. dimidiatus & + & + & + \\
\hline & Ptinidae & Lasioderma & L. serricorne & - & + & + \\
\hline & Silvanidae & Oryzaephilus & O. surinamensis & - & + & + \\
\hline & \multirow[t]{2}{*}{ Tenebrionidae } & Tribolium & T. castaneum & + & + & + \\
\hline & & Alphitobius & A. laevigatus & + & + & + \\
\hline \multirow[t]{4}{*}{ Lepidopetra } & Galeridae & Corcyra & C. cephalonica & + & + & + \\
\hline & Pyralidae & Pyralis & P. farinalis & - & + & + \\
\hline & Gelechiidae & Sitotroga & S. cerealella & + & + & + \\
\hline & Oecophoridae & Endrosi & E. sarcitrella & + & + & + \\
\hline Psocoptera & Psyllipsocidae & Liposcelidae & Liposcelis & - & + & + \\
\hline
\end{tabular}

The + and - signs indicate positive and negative pest insects found based on the corn storage area

\section{An abundance of Insect Pests in the Corn Warehouse in Sumbawa Regency}

\section{Abundance of Pest Insects in the Western Region}

There are two highest numbers of individual insect pests in the West, at the family and species levels obtained in the family Natidulidae, Carpophiluslugubris species with an abundance index of $72,19 \%$, and $19.12 \%$ in the Tenebrionidae family of the Triboliumcataneaum species. That is because both are from the same Ordo, the OrdoColeoptera which is known as a grain-eating insect. In addition to the Carpophiluslugubris and Triboliumcastaneum species of the families Natidulidae and Tenebrionidae, all other families and species have an abundance index of less than $10 \%$ (Table 3).

The two species above are pest species that are often found in storage sheds. Vega et al. (2019) states that Carpophiluslugubris is a primary pest in a storage warehouse originating from the OrdoColeoptera. While other reports mention that Triboliumcastaneum is called a pest insect that can damage storing materials up to $72 \%$ with a percentage decrease in the quantity of storing materials which ranges from $80 \%$.

In theory, the increase in pest populations, especially warehouse pests, is influenced by several factors such as foodstuffs, storage microclimates, and the state of natural enemies (Yasin, 2009). Food material in the form of corn storage material that invites the two species into a storage warehouse. The temperature conditions in the storage shed also support the presence of the two species above, namely $26-30 \mathrm{oC}$ which is a range of temperatures that can still be tolerated by both species. Natural enemies are not found in storage areas in this region, whereas the presence of natural enemies can reduce the abundance of insect pest populations by carrying out their function as a biotic mortality factor so that the insect pest population can be kept at a low level (Luff, 1983).

Table 3. Post-harvest Corn Insect Abundance in the Western Region Corn Storage Warehouse, Sumbawa Regency

\begin{tabular}{lllll}
\hline Ordo & Family & Species & Amount & Pi (\%) \\
\hline \multirow{2}{*}{ Coleoptera } & Bostrichidae & R. dominica & 72 & 0.68 \\
\cline { 2 - 5 } & Curculionidae & S. zeamais & 162 & 1.54 \\
\cline { 3 - 5 } & & A. fasciculatus & 17 & 0.16 \\
\cline { 2 - 5 } & Dermestidae & A. fasciatus & 3 & 0.03 \\
\cline { 3 - 5 } & & &
\end{tabular}




\begin{tabular}{lllll}
\hline Ordo & Family & Species & Amount & Pi $(\%)$ \\
\hline \multirow{5}{*}{ Lepidopetra } & Nitidulidae & C. lugubris & 7674 & 72.98 \\
\cline { 3 - 5 } & & C. dimidiatus & 530 & 5.04 \\
\cline { 2 - 5 } & Tenebrionidae & T. castaneum & 2010 & 19.12 \\
\cline { 2 - 5 } & Galeridae & A. laevigatus & 24 & 0.23 \\
\cline { 2 - 5 } & Gelechiidae & C. cephalonica & 14 & 0.13 \\
\cline { 2 - 5 } & Oecophoridae & S. cerealella & 4 & 0.04 \\
\hline
\end{tabular}

Pi: Pest Insect Abundance Index

\section{Abundance of Pest Insects in the Central Region (Midle)}

The highest population abundance index in the Central region was obtained in species of Liposcelis sp. from the Psyllipsocidae family, with an abundance index of $96.50 \%$, while a population abundance index in species and other families has a very small abundance of less than $3 \%$, as shown in Table 4.

The abundance of Liposcelis sp. in the Central Region it can be caused by the state of the micro environment that supports its growth and propagation. The humidity and temperature of the environment in the warehouse are at optimal conditions for the growth and development of Liposcelis sp., Ie the room temperature is approaching $30 \mathrm{oC}$ and the humidity nearing 60\%. Leong (1995) reported that Liposcelis sp. can grow and develop optimally at a temperature of $30 \mathrm{oC}$ with a relative humidity of $75 \%$. Liposcelis sp. is a warehouse pest which has the longest reported presence in a warehouse and causes a decrease in the quality and quantity of agricultural commodities (Turner, 1994).

Table 4. Post-harvest Corn Insect Abundance in Central Region Corn Storage Warehouse, Sumbawa Regency

\begin{tabular}{|c|c|c|c|c|}
\hline Ordo & Family & Spesies & Jumlah & $\overline{P i}(\%)$ \\
\hline \multirow[t]{12}{*}{ Coleoptera } & \multirow[t]{2}{*}{ Bostrichidae } & R. dominica & 191 & 0.10 \\
\hline & & D. minutus & 5 & 0.00 \\
\hline & \multirow[t]{2}{*}{ Curculionidae } & S. zeamais & 619 & 0.31 \\
\hline & & A. fasciculatus & 269 & 0.13 \\
\hline & Dermestidae & A. fasciatus & 15 & 0.01 \\
\hline & \multirow[t]{2}{*}{ Nitidulidae } & C. lugubris & 4308 & 2.16 \\
\hline & & C. dimidiatus & 406 & 0.20 \\
\hline & Ptinidae & L. serricorne & 47 & 0.02 \\
\hline & Silvanidae & O. surinamensis & 118 & 0.06 \\
\hline & \multirow[t]{3}{*}{ Tenebrionidae } & T. castaneum & 728 & 0.36 \\
\hline & & A. laevigatus & 167 & 0.08 \\
\hline & & C. cephalonica & 53 & 0.03 \\
\hline \multirow[t]{3}{*}{ Lepidopetra } & Galeridae & P. farinalis & 2 & 0.00 \\
\hline & Pyralidae & S. cerealella & 36 & 0.02 \\
\hline & Gelechiidae & E.sarcitrella & 20 & 0.01 \\
\hline Psocoptera & Psyllipsocidae & Liposcelissp. & 192669 & 96.50 \\
\hline
\end{tabular}

Pi: Pest Insect Abundance Index

\section{Abundance of Pest Insects in the Eastern Region}

The highest population abundance index in the Eastern region comes from two species consisting of two different families (Table 5). The species is Liposcelis sp. from the Psyllipsocidae family, with an abundance index of
76.97\%, and Carpophiluslugubris species from the Nitidulidae family with an abundance index of $11.74 \%$. In addition to the two species of the two families, the population abundance index of the species and other families has a very small abundance, which is less than $10 \%$ as species of 
Dinoderusminutus (Bostrichidae) and Endrosissarcirtella (Oecophoridae) with an abundance of 0, respectively, 02\%, and Pyralisfarinalis (Pyralidae) with an abundance percentage of $0.00 \%$.

Warehouse pest insects found in the Eastern Region are not much different from the other two regions. Liposcelis sp. previously found in the Central Region are also found in this region. The same applies to Carpophiluslugubris species that were previously found in the Western Region. Both species are found as the most abundant species in this region. This is presumably due to temperature and humidity factors which did not differ greatly in the three regions, although observations of minimum and maximum temperatures were found to be relatively different in the three regions.
Temperature and humidity in the Eastern Region is very supportive for the proliferation of Liposcelis $s p$. which is in the temperature range of $27-310 \mathrm{C}$ and relative humidity which ranges from $60-69 \%$. The condition of the microenvironment is considered as the optimum condition for growth and development of the two dominant pest insect species found in this Region. Liposcelis sp. can grow and develop optimally at a temperature of $30 \mathrm{oC}$ with a relative humidity of $75 \%$ (Leong, 1995). Whereas Carpophiluslugubris is known as a warehouse pest that attacks grains such as maize commodities (Turner, 1994). In addition, the Carpophiluslugubris species is a primary pest in a storage warehouse originating from the OrdoColeoptera (Vega et al., 2019).

Table 5. Abundance of Corn Insect Pest in the Eastern Region, Sumbawa Regency

\begin{tabular}{|c|c|c|c|c|}
\hline Ordo & Family & Species & Amount & $\operatorname{Pi}(\%)$ \\
\hline \multirow{11}{*}{ Coleoptera } & \multirow{2}{*}{ Bostrichidae } & R. dominica & 354 & 1.18 \\
\hline & & D. minutus & 7 & 0.02 \\
\hline & \multirow[t]{2}{*}{ Curculionidae } & S. zeamais & 319 & 1.07 \\
\hline & & A. fasciculatus & 139 & 0.46 \\
\hline & Dermestidae & A. fasciatus & 35 & 0.12 \\
\hline & \multirow[t]{2}{*}{ Nitidulidae } & C. lugubris & 3515 & 11.74 \\
\hline & & C. dimidiatus & 122 & 0.41 \\
\hline & Ptinidae & L. serricorne & 6 & 0.02 \\
\hline & Silvanidae & O. surinamensis & 35 & 0.12 \\
\hline & \multirow[t]{2}{*}{ Tenebrionidae } & T. castaneum & 2256 & 7.54 \\
\hline & & A. laevigatus & 35 & 0.12 \\
\hline \multirow[t]{4}{*}{ Lepidopetra } & Galeridae & C. cephalonica & 18 & 0.06 \\
\hline & Gelechiidae & S. cerealella & 44 & 0.15 \\
\hline & Oecophoridae & E. sarcitrella & 7 & 0.02 \\
\hline & Pyralidae & P. farinalis & 1 & 0.00 \\
\hline Psocoptera & Psyllipsocidae & Liposcelissp. & 23040 & 76.97 \\
\hline
\end{tabular}

Pi: Pest Insect Abundance Index

\section{CONCLUSION}

The diversity of warehouse pest insects in Sumbawa is classified as low with a diversity index $\left(\mathrm{H}^{\prime}\right)$ in the three regions of less than one $\left(\mathrm{H}^{\prime}<1\right)$. The most commonly found Ordois the OrdoColeopteraand the least is Psocoptera. The abundance of corn barn pest insects is dominated by the OrdoPsocoptera (Liposcelis sp.) For the Central and Eastern regions with an abundance index of $96 \%$ and $76 \%$, and the OrdoColeoptera (Carpophiluslugubris) for the Western region with an abundance index of $72 \%$.

\section{AKNOWLEGDEMENTS}

This research was part of the first author Master Degree Project at Dryland Resource Management, University of Mataram. A million thanks to my lovely wife who always support me to do this research project.

\section{REFRENCES}

[1] Sumbawa Regency Agriculture Service. 2018. Data on Planting Area and Food Security Production. Sumbawa.

[2] Halid, $\mathrm{H}$ and Yudawinata. 1983. Types of BULOG Warehouse Storage Pests and Control Businesses. Paper 
Presented at the Second Entomology Congress, January 2426 1983, in Jakarta.

[3] Morallo\&Rejesus. 1978. inWahyuningsih, S. 2000. Study of Insecticide Power of Pariah Seeds and Noni Seed Extract on the Development of Insect SitophiluszeamaisMotsch. Thesis. FATETA. Bogor Institute of Agriculture, Bogor.

[4] Christensen, C.M. and H.H. Kaufmann. 1969. Microflora. p. 158-191. In C.M. Cristensen (Ed.). Storage of Cereal Grains and Their Products. American Association of Cereal Chemist Inc., St. Paul.

[5] Rees, D. 2004. Insect of Stored Products.CSIRO Publishing. Australia. p.18.

[6] Haines, C. P. 1991. Insect and arachinids of tropical stored product their biology and identification. Natural resource institue, central avenue chatam maritime kentmey 4 TB. United Kingdom.

[7] Sembel, D.T, J. Rimbing, D. Kandowangko, 2002. Inventory and Identification of warehouse pests in grains as well as population development and loss and grain by pests. Collaborative Education for community Food Enterprice Development A\&M University system and department of pests and plant diseases Faculty of Agriculture Unsrat.

[8] Wagiman, F.X. 2015. Postharvest Pest and Its Management. Second printing. GadjahMada University Press, Yogyakarta.

[9] Krebs, C.J. 1978. Ecological Methodology. New York: Harper and Row Publisher.

[10] Miriam Sanchez Vega, Alonso Mendez Lopez, Jose C. Salazar Torres, Aida I. Leal Robles, Sylvia Y. Martinez Amador, and Jose E. Perez Perez. 2019. Diversity of Insect Pest Damaging Quality of "Huitlacoche" (Corn Smut) at Saltillo, Coahuila, Mexico. Southwestern Entomologist. Vol 44, Issue 3, p.627-636.

[11] Yasin, M., 2009. Ability to Access Insect Powder Beetle Pests and Physiochemical Factors That Affect it. Proceedings of the 2009 national cereals seminar. Cereals research center. ISBN: 978-979-8940-27-9.

[12] Luff, M.L. 1983. The Potential of Predators for Pest Control. Agriculture, Ecosystem \& Environment. Vol. 10, Issue 2, p.159-181.

[13] Turner, B. D. 1994. Liposcelis bostrichophila (Psocoptera: Liposcelididae), a stored food pest in the UK. International Journal of Pest Management, 40:2, p.179-190. 